\title{
PRODUCTION AND ECONOMIC ANALYSIS OF A POP-UP FARM IN MEXICO CITY
}

\author{
P.D.H. GUERRERO ${ }^{1}$, L.M.M. MATA ${ }^{1}$, P.B. MADRIGAL ${ }^{1}$ \& J.J.M. CRIOLLO ${ }^{2}$ \\ ${ }^{1}$ Mechanical Engineering, Engineering Faculty, La Salle University, Mexico. \\ ${ }^{2}$ Solid State Section, Centro de Investigación y de Estudios Avanzados, Mexico.
}

\begin{abstract}
Urban agriculture is becoming a relevant strategy to increase the resilience in highly populated cities since it helps in addressing urban food scarcity, malnourishment and obesity problems, may provide alternative economic opportunities and improves environmental quality. Mexico City is facing numerous challenges related with the fast growth of its population that threatens its ability to keep up providing them with basic food and water services. Low prices of processed foods associated with industrial agriculture, combined with the urbanization lifestyle, have left Mexico City with a public health crisis. To contribute to solving these problems, it is proposed to use several Pop-Up Farms using Mel Bartholomew's system for the cultivation of local vegetables (tomatoes, romaine lettuce, pepper, spinach, onions, celery, etc.), taking advantage of the city's subtropical highland climate and a specially designed rainwater harvesting system. Preliminary results show that a Pop-Up Farm can supply a significant fraction of the average yearly family consumption for these vegetables in the region. A cost benefit analysis shows that Pop-Up Farms are a viable strategy for providing high-quality food at low costs contributing to increase health and economic conditions in urban environments.
\end{abstract}

Keywords: cultivation table, low cost, Mel Bartholomew's system, rainwater, urban agriculture

\section{INTRODUCTION}

Urban agriculture is not a recent concept in Mexico City. The first human settlements in the area, the Aztecs, in Teotihuacan, were immersed in a complex agricultural landscape. As a result, they established amazing agriculture methods. The most popular is the one called chinampas, still used nowadays [1,2]. In Mexico City, urban agriculture coexists in urban and peri-urban areas between rural and urban environments. For example, peri-urban farmers that work in typical jobs (guards, civil servants, construction workers, etc.) during weekends, work their crop fields. They represent $0.7 \%$ of the urban population [3].

A limiting factor for urban and peri-urban agriculture to represent a viable strategy to increase food supply and improve urban conditions is the lack of economic incentives. Mexican policies are not currently focused on the development of national urban agriculture. One of the most important urban agriculture programs in Mexico City is the 'Sustainable Small-scale Agriculture' (ASPE) supported by the Ministry of Rural Development and Equity for Community (SEDEREC is the acronym in Spanish). The City Government organizes this program every year with the objective of giving economic support to projects where self-consumption and commercialization of organic foods at small scale are implemented. In 2017, 131 projects in the 'Promote Urban Agriculture' division were approved [4].

On the other hand, in industrialized countries where food security is not compromised, urban agriculture is viewed more as a recreational exercise than an actual activity for food production. However, in developing countries like many Latin American's it has become a relevant activity for food production [5].

In this paper, we are proposing the use of two Pop-Up Farms cultivation tables in Mexico City, in Gustavo A. Madero Municipality. In this location, like most of the city, we can find 
great economic inequalities and underdevelopment. According to the National Institute of Statistics and Geography [6], approximately $10.8 \%$ of the people in the area are affected by food scarcity. Additionally, data of urban agricultural production in the zone is missing. As the Food and Agriculture Organization observes, urban agriculture in this part of Mexico City is in its beginning [7].

A significant advantage to maximize production of our Pop-Up Farming cultivation tables is that they follow the empirical Mel Bartholomew's system (MB system) [8]. We build the two elevated cultivation tables according to the technique 'Square meter gardening', in a space of $1 \mathrm{~m}^{2}$, it is feasible to plant crops that provide fresh vegetables for one person all year round. Following Bartholomew's method, the crops are rotated according to their harvest cycles. Furthermore, the MB system identified, by experimental research, the best mix of soil and the necessary space each crop needs to allow using the whole growing area. We choose the MB system due to its simplicity. It can be operated by a common person (non-agricultural). Finally, to evaluate the economic benefits that represent our production, we have done a costbenefit analysis which consists of a comparison between the expected results of the MB system with our results.

To our knowledge, the use of the rainwater in Mexico City is rather scarce, despite Mexico having the conditions to exploit this resource given its geographic location and weather. There is a minimal amount of recycled water or rainwater harvest in houses. Furthermore, the drinking water supplies in Mexico City are an increasing problem as a result of the overpopulation, poor urban planning, general contamination and lack of regulations to enforce proper waste water treatment. In the present work, we will address the benefits of implementing a rainwater harvest system for crop irrigation [3].

This paper is organized as follows. Section 2 describes the implementation of the cultivation tables and the design of the rainwater capture system. Section 3 contains the procedure of the costbenefits analysis. In Section 4, we present the performance of the two cultivation tables and their corresponding economic analysis. Section 5 presents discussions and concluding remarks.

\section{CONSTRUCTION OF THE CULTIVATION TABLES}

This section briefly describes the two cultivation tables used in this work based on the MB system and complemented by an ad-hoc rainwater harvesting system.

The cultivation tables were placed following the three main factors of the MB system: (i) it must be easily accessible to the user to facilitate plant care and crop harvest, (ii) it should have between 6 and $8 \mathrm{~h}$ of sunshine per day and (iii) a suitable drainage system must be ensured to prevent excess humidity in the cultivation tables' substrate (ground). The location of the cultivation tables is presented in Fig. 1.

We have used the recommended procedures to design and build the two elevated cultivation tables. The MB system suggests that approximately $30 \mathrm{~cm}$ depth of soil mixture is suitable to plant all kinds of crops. The cultivation tables were manufactured using common and widely available materials, such as ordinary wood panels, bricks, plastic, nails and screws. The first cultivation table, labelled as $E$ in Fig. 1 , is $1 \mathrm{~m}^{2}$ with $30-\mathrm{cm}$ depth where crops that develop larger roots were placed and the second one, $F$, is $1.8 \mathrm{~m} \times 1 \mathrm{~m}$ with $15-\mathrm{cm}$ depth were adequate crops were planted. Different sizes were used for two main reasons, the material and space we had available. Following the MB method, both cultivation tables were divided into rectangular sections of at least $30 \mathrm{~cm}$ per side as indicated in Fig. 2. The area of the sections provides the necessary space for each plant when they are mature. Cultivation 


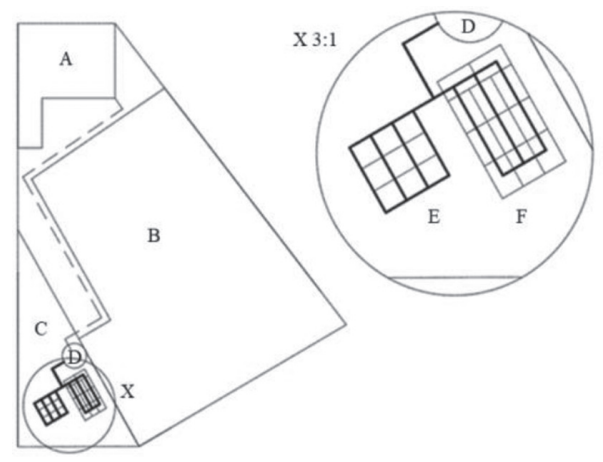

Figure 1: Plan view of the location of the cultivation tables where $A$ is the rainwater harvest area (approx. $14 \mathrm{~m}^{2}$ ), B is the total area of the house's roof of $100 \mathrm{~m}^{2}, \mathrm{C}$ is the location area of the cultivation tables, $\mathrm{D}$ is the water tank and $\mathrm{E}$ and $\mathrm{F}$ are the cultivation tables. The irrigation system is represented by a bold line above $\mathrm{E}$ and $\mathrm{F}$ and the rainwater harvesting system by a dashed line.

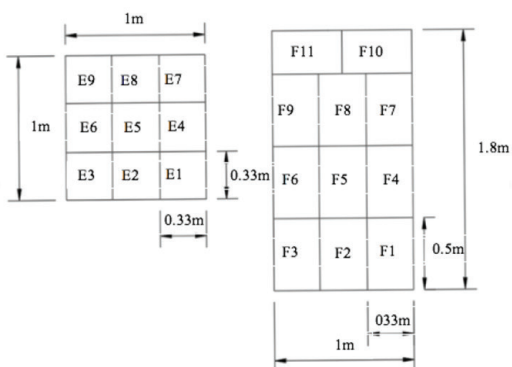

(a)

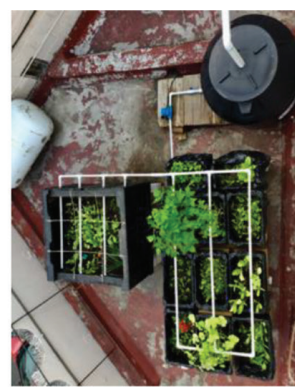

(b)

Figure 2: Cultivation tables. (a) Identification of sections of both cultivation tables $\mathrm{E}$ and $\mathrm{F}$. (b) Photo of the corresponding cultivation tables.

table $E$ was divided into nine sections E1E9, while cultivation table $F$ was divided into 11 sections F1-F11.

\subsection{Crop selection}

Mexico City presents an advantage due to the weather conditions which are favourable for flora's development. The climate is mild and moderate to abundant rainfall in summer. The average annual temperature is $16^{\circ} \mathrm{C}$, highest temperatures $\left(25^{\circ} \mathrm{C}\right.$ approx.) are reached from March to May and the lowest $\left(5^{\circ} \mathrm{C}\right.$ approx.) during January [6].

For this work, a mixture of 12 crops and herbs commonly found in a Mexican diet were selected: onion, celery, coriander, lettuce, arugula, radish, spinach, pumpkin, bean, pea, pepper and tomatoes. This selection allows harvesting all year round due to their cultivation season. Crop type and number of sowed seeds per section are shown in Table 1. In section F11, tobacco and chamomile were cultivated as pest repellent and they are not considered for final results. 
Table 1: Number of plants by section of cultivation tables.

\begin{tabular}{|c|c|c|c|}
\hline Plant & Section & Number of plants per section & Total \\
\hline Onion (Liliaceae) & E1, E7, E8, E9 & $3,4,5,5$ & 17 \\
\hline Celery (Umbellate) & F6 & 8 & 8 \\
\hline Coriander (Umbellate) & F11 & 10 & 10 \\
\hline Lettuce (Composite) & $\mathrm{E} 4, \mathrm{E} 8, \mathrm{E} 9, \mathrm{~F} 4, \mathrm{~F} 5$ & $2,4,2,6,6$ & 20 \\
\hline Radish (Cruciferous) & E5, E6 & 10,10 & 20 \\
\hline Spinach (Chenopodiaceae) & F7 & 20 & 20 \\
\hline Pumpkin (Cucurbitaceae) & $\mathrm{F} 2$ & 4 & 4 \\
\hline Arugula (Composite) & E7 & 4 & 4 \\
\hline Bean (Labiates) & F9 & 16 & 16 \\
\hline Pea (Solanaceae) & F8 & 16 & 16 \\
\hline Pepper (Solanaceae) & $\mathrm{F} 1, \mathrm{~F} 3$ & 2,2 & 4 \\
\hline Tomato (Solanaceae) & E2, E3 & 1,2 & 3 \\
\hline
\end{tabular}

\subsection{Substrate}

The substrate used in the cultivation tables is a mixture of three equal parts of coconut fibre, worm humus and compost, commonly known as Mel Mix [9]. The coconut fibre, used as a component of peat-based substrates, provides a moisture retention capacity $(66 \%)$, a high aeration of the root system, buffer capacity ( $\mathrm{pH} 5)$ and electrical conductivity of the medium $(2.15 \mathrm{mS} / \mathrm{cm})[10]$. Compost is characterized by keeping the micro fauna in balance, having low levels of salinization, high cation exchange capacity as well as maintaining the physical structure that allows water and air flowing permanently. Finally, worm humus is a substrate with high microorganism content which allows an increase in the biological activity of the soil that in turn improves crops resistance against plagues and diseases [11].

\subsection{Germination and heights of the crops}

For the cultivation tables, seeds from a supplier were used in Mexico City, 'Los Molinos' ranch [12]. It was possible to plant the first part of the seeds corresponding to the cultivation table E on July 1st. Due to the delay in obtaining the remaining seeds and the materials for the required mixture of the method, the second part of the seeds which corresponds to the cultivation table F, were planted on July 14.

For the days of germination expected, we rely on the information provided by the seed supplier [12]. Germination days were considered as the days in which we saw leaves bud for the first time. Heights were measured daily and were compared with Mel Bartholomew expected cultivation times [8]. Also, we checked the recommended season of cultivation. The detailed information is presented in Table 2 .

\subsection{Irrigation system}

As a first approach, an irrigation schedule using a total of $30 \mathrm{~L}$ of water every 2 days was deemed adequate to maintain optimal humidity conditions in both cultivation tables for the whole experimental period. The irrigation was performed by an automatized ad-hoc system 
Table 2: Germination date and expected heights.

\begin{tabular}{|c|c|c|c|c|c|c|}
\hline \multicolumn{2}{|c|}{ Our experimental data } & \multicolumn{2}{|c|}{$\begin{array}{l}\text { 'Los Molinos' } \\
\text { Ranch [12] }\end{array}$} & \multicolumn{3}{|c|}{ Mel Bartholomew [8] } \\
\hline Plant & $\begin{array}{l}\text { Recorded } \\
\text { germ. date }\end{array}$ & $\begin{array}{l}\text { Max. } \\
\text { expected } \\
\text { germ. } \\
\text { days }\end{array}$ & $\begin{array}{l}\text { Min. } \\
\text { expected } \\
\text { germ. } \\
\text { days }\end{array}$ & $\begin{array}{l}\text { Max. } \\
\text { expected } \\
\text { height } \\
(\mathrm{cm})\end{array}$ & $\begin{array}{l}\text { Min. } \\
\text { expected } \\
\text { height } \\
(\mathrm{cm})\end{array}$ & Cultivation season \\
\hline Onion & July 10th & 14 & 10 & 30 & 30 & Spring and summer \\
\hline Celery & August 14th & 20 & 14 & 40 & 40 & Summer and autumn \\
\hline Coriander & July 24th & 12 & 8 & 45 & 30 & Spring and summer \\
\hline Lettuce (E) & July 8th & 10 & 5 & 30 & 15 & Summer and autumn \\
\hline Lettuce (F) & July 22th & 10 & 5 & 30 & 15 & Summer and autumn \\
\hline Radish & July 4th & 6 & 4 & 30 & 15 & Summer and autumn \\
\hline Spinach & July 24 th & 12 & 8 & 30 & 15 & $\begin{array}{l}\text { Spring, autumn and } \\
\text { winter }\end{array}$ \\
\hline Pumpkin & July 20th & 8 & 6 & 120 & 45 & Summer \\
\hline Arugula & July 12th & 14 & 10 & 25 & 15 & $\begin{array}{l}\text { Spring, summer and } \\
\text { autumn }\end{array}$ \\
\hline Bean & July 18th & 6 & 4 & 200 & 150 & Summer \\
\hline Pea & July 20th & 6 & 3 & 150 & 60 & Spring and Summer \\
\hline Pepper & July 29th & 20 & 15 & 60 & 30 & Summer \\
\hline Tomato & July 26th & 14 & 10 & 200 & 200 & Summer \\
\hline
\end{tabular}

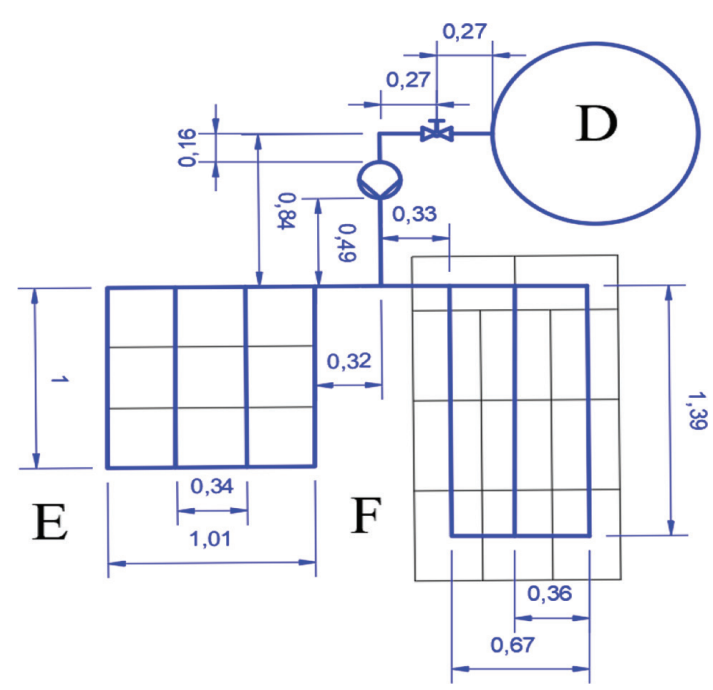

Figure 3: Irrigation system. The blue line represents a set of conduction, valves, PVC connections and distribution pipes installed on the cultivation tables. Here D is the water tank. 
that collects rainwater and distributes it with an $1 / 6 \mathrm{hp}$ water pump. It is estimated that in a $14 \mathrm{~m}^{2}$ area, it is possible to collect up to $47 \mathrm{~m}^{3}$ yearly of water given current rainfall conditions in Mexico City easily covering the water needs of the proposed system.

Data including substrate humidity and $\mathrm{pH}$ levels (using a Soil Meter sensor), germination period and plant height are logged manually daily. Although not ideal, plant height was used in this work as a measurement of preliminary system performance given that the experiments are ongoing.

\section{COST BENEFIT ANALYSIS}

A financial model that considers the benefits of the Pop-Up Farm system (cultivation tables, rainwater capture and irrigation systems) and the costs of water, energy usage, implementation, maintenance and operation is developed to evaluate its strengths and weaknesses.

\subsection{Categorization of expenses}

A list of the expenses incurred during the construction of the proposed production system was recorded to compare and ensure that future designs are more efficient economically and to potentially assess the its lifecycle at the end of the harvest period.

Expenses associated with the construction of the cultivation tables and the rainwater harvest and irrigation systems are considered as implementation costs. Expenses that are directly related to keeping the production system infrastructure in good working order are considered as maintenance costs.

\subsection{Financial model}

A financial model was built to allow estimations of the expenses that a family might incur to purchase their vegetables and to be able to assign a utility to the vegetables produced by the production system $[13,14]$. The following data is considered in the model: current inflation rate in Mexico based on monthly consumer price index (CPI) from the past 5 years, current minimum wage in Mexico City; monthly transportation cost (one trip formed by one round subway fare and one round bus fare) incurred to purchase the vegetables [15] in the biggest city market, known as Central de Abastos. It is worth noting that although smaller open markets are common across Mexico City, it is fairly common to purchase family vegetables from the central market due to their lower prices.

In our financial model, the following assumptions were made: inflation rate of $6 \%$, monthly minimum wage (\$88.35 MXN) and transport spending (\$44.18 MXN) [16].

To estimate a crop's maximum gross financial potential from the production system, the annual production for each crop shown in Fig. 6 is multiplied by the maximum retail price [15] in the market Central de Abastos. In this preliminary study, the prices for August are assumed as constant disregarding seasonal variation in prices. The total gross potential financial gain of production system is simply the total for all crop.

The net financial potential gain of the production system is the estimated gross gain after deducting maintenance expenses. Implementation costs are only considered in the first year because it is the amount of capital required to build the whole system.

\subsection{Study case}

A study case is proposed to estimate the potential financial benefits that a family might have from growing their own vegetables at their home when compared with the economic cost and 
time invested in purchasing from the market. For this, the net financial potential, based on central market prices [15], is extrapolated to a 5-year period, assuming prices and expenses increase with inflation rate while system production is assumed constant.

\section{RESULTS}

This section presents measured system results from germination time, plant height, plant growth rate and crop production. From these, results from the costbenefit analysis are presented.

\subsection{Germination time}

The measured germination time for each kind of vegetable is presented in Fig. 4. The results are compared with minimum and maximum expected germination times reported by $[8,12]$ and shown in Table 2. Note that the germination times presented for most in the production system are between the expected ones [17]. For other vegetables (e.g. beans, pumpkin and radish), the germination period is close to the minimum expected. This might be related with weather conditions in Mexico City with average annual temperature of $16^{\circ} \mathrm{C}$ that is beneficial for these crops (seed instructions recommend, for an optimal period of germination, an average annual temperature of $15^{\circ} \mathrm{C}$ ).

\subsection{Plant height}

The measured plant height after 50 days is presented in Figs. 5 and 6 compared with the expected height values reported by Mel Bartholomew for harvest time [8]. Note that after approximately 45 days, just a few plants have reached harvest time, specifically: coriander and radish. As is clearly seen in Fig. 5, the heights of the plants reached in the proposed production system are lower than the maximum expected heights for all crops: this is expected since the plants have not reached harvest time (only onion, lettuce, radish and spinach reached the minimum expected heights, based on Mel Bartholomew's work [8], within the measured timeframe) by the time reported in Fig. 5.

It is possible to observe that except for coriander and radish, our vegetables are around $50 \%$ of the required days, despite being planted in the recommended season presented in Table 2. It is important to mention that the present results are preliminary due to the fact that almost all the crops continue within the growth period to reach their expected height. Even

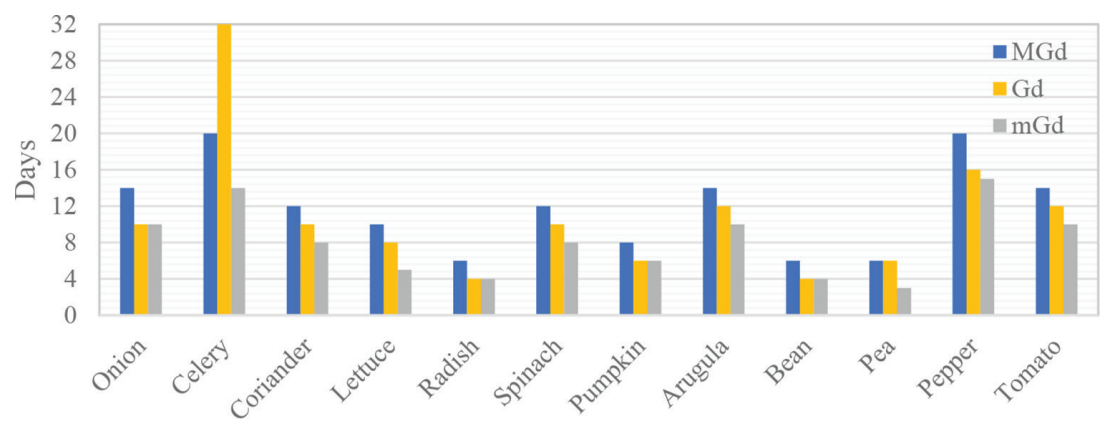

Figure 4: Germination vs days. MGd are the maximum expected germination days, Gd are the germination days presented in our system and $\mathrm{mGd}$ are the minimum expected germination days. 


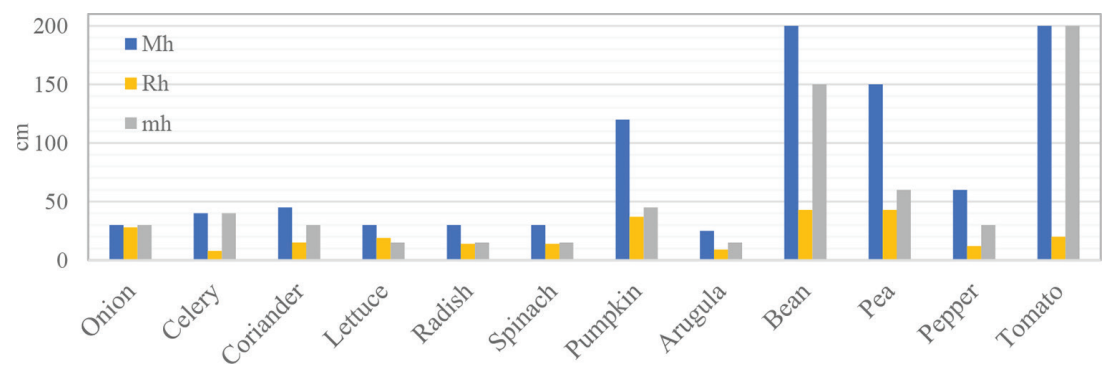

Figure 5: Heights of plants. Mh are the maximum expected heights, Rh are the heights reached by the plants in the proposed production system and $\mathrm{mh}$ are the minimum expected heights.

so, we discovered that in the case of the onion, lettuce, spinach and pumpkin, it is possible to obtain at least the minimum expected heights in fewer days.

\subsection{Production}

In Fig. 6, we display the values estimated for our production. Unfortunately, due to the lack of time, we estimated the production with a rough comparison of time and heights. Of course, such simplifications do impose some limitations on the costanalysis results. Once we had the final production, a natural further step would be to remove the production's estimated values.

With the results obtained in the plant's heights vs. the days elapsed and comparing with the corresponding expected values reported by [8], we calculate the performance per vegetable. The results of this approach are as follows: onion $210.8 \%$, celery $58.3 \%$, coriander $24.3 \%$, lettuce $214.5 \%$, radish $21.1 \%$, spinach $81.7 \%$, pumpkin $54 \%$, arugula $65 \%$, bean $62.7 \%$, pea $58.5 \%$, pepper $72.9 \%$ and tomato $28.2 \%$. To use as a reference, $100 \%$ is when the vegetable reaches the minimum height within the expected time period reported by [8]. Finally, we multiply the expected production data by the obtained performance's percent and the number of plants in our system.

Our production results using the performance approach shows that crops such as coriander, radish, pumpkin, arugula, bean, pea, pepper and tomato need the complete period of days to

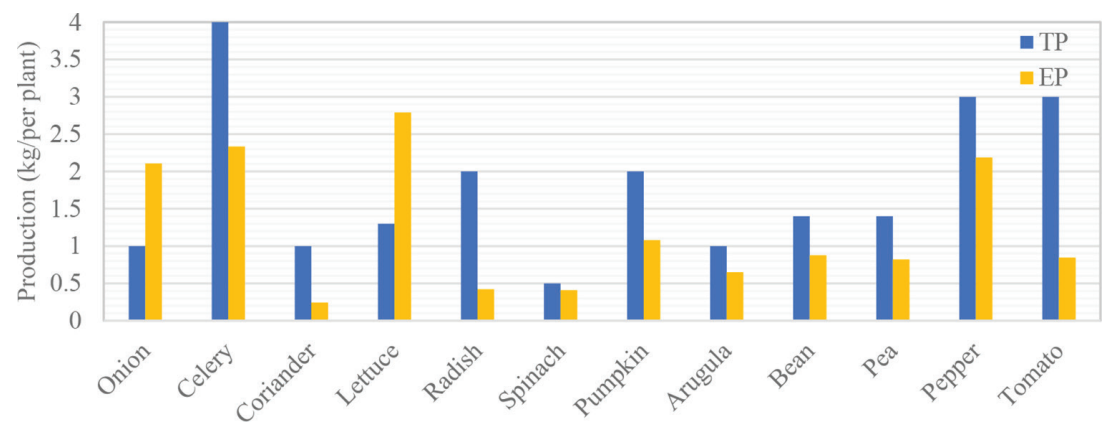

Figure 6: Production per plant. TP are the expected production and EP are the estimated production. 
Table 3: Costbenefit results projected for 5 years.

\begin{tabular}{llllll}
\hline & Year 1 & Year 2 & Year 3 & Year 4 & Year 5 \\
\hline Income (in \$) & $7,167.49$ & $7,525.6$ & $7,902.16$ & $8,297.26$ & $8,712.13$ \\
Operating expenses (in \$) & $3,729.82$ & $3,891.31$ & $3,970.06$ & $4,052.75$ & $4,139.57$ \\
Net operating expenses & $3,437.67$ & $3,634.55$ & $3,932.09$ & $4,244.51$ & $4,572.55$ \\
(in \$) & & & & & \\
Implementation costs (in \$) & $10,194.00$ & - & - & - & - \\
Net income (in \$) & $6,756.33$ & $3,634.55$ & $3,932.09$ & $4,244.51$ & $4,572.55$ \\
\hline
\end{tabular}

reach the expected production, whereas vegetables such as onion and lettuce grow in a faster rate than the expected values. However, due to the fact that the vegetables are for selfconsumption, it will not be difficult to provide enough time for the vegetables to reach the corresponding size and obtain better results.

Now we turn to the costbenefit analysis. The results obtained for the projection of the expenses and production over 5 years are presented in Table 3. This table shows evidence of the advantages of using cultivation tables. The macroeconomic effects such as inflation and loss of purchasing power can be minimized.

The projection shows that the 'income' and the 'operating expenses' during 5 years in our system increases slightly. Only in 'Year 1' it is necessary to consider the implementation cost. It is important to realize that this cost can be lower if you include more recycled material. However, just in 'Year 1' the system exhibits economical losses, but for the rest of the years the system presents incomes. As a matter of fact, these incomes also increase slightly.

In comparison, the price of the vegetables in retail markets are subject to several factors as well as costs including the use of pesticides, harvest labour, transportation, refrigeration, distribution and storage that are difficult to predict and might become even higher in highly populated areas far from agricultural centers. In contrast, cost associated with crops from Pop-Up Farms have the potential to be more stable due to their simpler production system.

\section{CONCLUDING REMARKS}

This work has presented preliminary results from the implementation of a Pop-Up Farm system that consists of two cultivation tables using Mel Bartholomew's method and an ad-hoc irrigation system with rainwater harvesting. It has been shown that it is a relatively easy method in terms of manufacture and operation with the additional advantage of low costs suitable to be implemented in highly populated urban areas.

System production at this point has been estimated using crop heights at early growth stages and comparing it with estimated heights from seed producers. Validation of this methodology will be tested once actual harvest results are obtained and will be published accordingly.

A simple economic model has been used to estimate the potential economic benefits of Pop-Up Farms showing that even with low crop performances the system presents net incomes that increase slightly over time making them a viable economic opportunity. Improvements considered for future designs include the use of a higher proportion of recycled materials that meet the operational requirements of the cultivation tables.

In highly populated areas in developing countries, such as Mexico City, Pop-Up Farms present multiple additional benefits such as reducing the energy usage in crop transportation, 
refrigeration, distribution and storage; reduce packaging-related waste; and increase poor families access to fresh vegetables contributing to an overall improvement in nutrition, food security and health conditions.

For a megacity such as Mexico City, urban agriculture can contribute to a better nutrition and economy since this model can be available for a poor population to have an improvement in terms of food security and health conditions. Human health through food safety and diversified diet is becoming an urgent issue for governments. Urban farming may not be the solution to solve food scarcity, but it is a way to establish condition for permanent upgradable systems able to adapt to an environment that changes day by day.

\section{ACKNOWLEDGMENTS}

The authors gratefully acknowledge the assistance of Rodrigo Olivares Ronces in the costbenefit analysis and for useful discussion about the economic benefits of our system.

P. Burgos Madrigal thanks Pablo David Hernández Guerrero and Luis M. Moran Mata for funding the construction of the system and research.

This research did not receive any specific grant from funding agencies in the public, commercial or not-for-profit sectors.

\section{REFERENCES}

[1] Losada, H., Martínez, H., Vieyra, J., Pealing, R., Zavala R. \& Cortés, J., Urban agriculture in the metropolitan zone of Mexico City: changes over time in urban, suburban and peri-urban areas. Environment and Urbanization, 10(2), 37-54, October 1998. https://doi.org/10.1177/095624789801000214

[2] Losada, H., Bennett, R., Soriano, R., Vieyra, J. \& Cortés, J., Urban agriculture in Mexico City: functions provided by the use of space for dairy based livelihoods. Cities, 17(6), 419-31, 2000. https://doi.org/10.1016/s0264-2751(00)00041-x

[3] Torres Lima, P., Rodríguez, L.M. \& García Uriza, B.I., Mexico city: the integration of urban agriculture to contain urban sprawl. City Case Study Mexico, pp. 364-90, 21 December 2014.

[4] Secretaría de Desarrollo Rural y Equidad para las Comunidades (SEDEREC), Agricultura sustainable a pequeña escala. ASPE, 2017 [Online]. Available: https://sederec.cdmx.gob.mx/programas/programa/programa-agricultura-sustentable-pequenaescala-de-la-ciudad-de-mexico (accessed 7 June 2018).

[5] Pérez Rodríguez, G.I., Delgado Morales, R. \& Bernal Negrete, L.G., Agricultura urbana: una alternativa sustentable para el desarrollo genereal. In 21 Encuentro Nacional sobre Desarrollo Regional en México, Mérida, 2016.

[6] Instituto Nacional de Estadística y Geografía (INEGI), Information by entity. 2018. [Online]. Available: http://cuentame.inegi.org.mx/monografias/informacion/df/territorio/clima.aspx?tema=me\&e=09 (accessed 1 June 2018).

[7] Food and Agriculture Organization, Food Security indicators. Food and Agriculture Organization of the United Nations, October 2017 [Online]. Available: http://fao.org/ economic/ess/ess-fs/ess-fadata/en/\#.W4Vqt2dBCFM (accessed May 2018).

[8] Bartholomew, M., Square Meter Gardening, Barcelona: Blume, 2016.

[9] ABC del Huerto Urbano [Interview]. 4 May 2018.

[10] Quiñonez Ferandez, M.V., Use of Coconut Fiber as a Substrate, Rafael Landívar University: Guatemala, 2014. 
[11] Agricultural Clinic Group, Earthworm humus, vermiculture, 2018 [Online]. Available: http://bioagrotecsa.com.ec/lombricultura/humus-de-lombriz.html (accessed 3 June, 2018).

[12] Rancho los Molinos, Vita, Buscador de Semillas. Rancho los molinos, 2018 [Online]. Available: http://losmolinos.com/vita/vita.html\#one (accessed 5 June 2018).

[13] Instituto Nacional de Estadística y Geografía (INEGI), Encuesta Nacional de Ingresos y Gastos de Hogares, 2016 [Online]. Available: http://beta.inegi.org.mx/contenidos/proyectos/enchogares/regulares/enigh/nc/2016/doc/presentacion_resultados_ enigh2016.pdf (accessed 2018).

[14] Instituto Nacional de Estadistíca y Geografía (INEGI), Comunicado de prensa. 2016. [Online]. Available: http://inegi.org.mx/saladeprensa/boletines/2017/enigh/enigh_08. pdf, 2016 (accessed 2018).

[15] SNIIM, Sistema Nacional de Información e Integración de Mercados. SNIIM, 17 June 2018 [Online]. Available: http://economia-sniim.gob.mx/2010prueba/FrutasFec.asp (accessed 17 June 2018).

[16] Servicio de Administración Tributaria (SAT), Salario Minimos 2018 [Online]. Available: http://omawww.sat.gob.mx/informacion_fiscal/tablas_indicadores/Paginas/ salarios_minimos.aspx (accessed 30 Agosto 2018).

[17] Morrow, J., Vegetable Gardening for Organic and Biodynamic Growers, SteinerBooks, Incorporated, 2014.

[18] Barkin, D., La gestión del agua urbana en México. In La gestión del agua urbana en México: retos, debates y bienestar, Guadalajara, Universidad de Guadalajara, pp. 3-6, 2006.

[19] NASA Surface meteorology and Solar Energy, Atmospheric Science Data Center, 2018 [Online]. Available: https://eosweb.larc.nasa.gov/cgi-bin/sse/retscreen.cgi?email $=$ rets $\% 40 \mathrm{nrcan} . \mathrm{gc} . \mathrm{ca} \& \mathrm{step}=1 \& \mathrm{lat}=19.507788 \&$ lon $=-99.097626 \&$ submit $=$ Submit (accessed 1 June 2018).

[20] Dieleman, H., Urban agriculture in Mexico City: balancing between ecological, economic, social and symbolic value. Journal of Cleaner Production, 163, pp. S156-S163, 1 October 2017.

[21] Forbes, Forbes México, 19 February 2015 [Online]. Available: https://forbes.com.mx/ mexicanos-gastan-50-del-ingreso-familiar-en-transporte/ (accessed 3 May 2018).

[22] Instituto Nacional de Estadística y Geografía (INEGI), Indice de precios. INEGI, 27 May 2018 [Online]. Available: http://beta.inegi.org.mx/app/indicesdeprecios/Estructura.aspx? idEstructura $=112000200040 \& \mathrm{~T}=\% \mathrm{C} 3 \% 8$ Dndices $\% 20 \mathrm{de} \% 20$ Precios $\% 20$ al\%20Consumidor\&ST=Inflaci\%C3\%B3n (accessed 17 June 2018).

[23] SEDESOL, Gobierno de Mexico, Secretaria de Desarrollo Social, 2017 [Online]. Available: https://gob.mx/sedesol (accessed Junio 2018).

[24] Secretaría de Hacienda y Crédito Público (SHCP), Servicio de administracion tributaria. SAT, 21 December 2017 [Online]. Available: http://omawww.sat.gob.mx/informacion_fiscal/tablas_indicadores/Paginas/salarios_minimos.aspx (accessed 17 June 2018). 